\title{
МЕДІАГРАМОТНІСТЬ У СУСПІЛЬНО-ГУМАНІТАРНОМУ ЦИКЛІ ДИСЦИПЛІН ОСВІТНЬО-ПРОФЕСІЙНОЇ ПРОГРАМИ ПІДГОТОВКИ ЗДОБУВАЧІВ ВИЩОЇ ОСВІТИ
}

\section{Ільченко О. А.}

\section{ВСТУП}

Готувати молодь до свідомої діяльності в медіасередовищі через формування критичного ставлення до медіапродукції, перетворювати здобувачів вищої освіти на свідомих і творчих користувачів масмедіа, сприяти виробленню імунітету до маніпулятивної дії екрану, тобто створювати умови інформаційної безпеки, не $\epsilon$ можливим без опанування основ медіаграмотності ${ }^{1}$. Медіаграмотність - це комплекс навичок i знань, необхідних людині в сучасному інформаційному суспільстві ${ }^{2}$.

Зростання ролі медіа в освітніх процесах, зміна «дидактичного ландшафту», в умовах якого здійснюється підготовка здобувачів вищої освіти до життя в інформатизованому суспільстві, вимагають визначення змісту медіаосвіти й шляхів її впровадження в педагогічну практику. Цим питанням було присвячено Міжнародну науково-практичну інтернетконференцію «Медіаосвіта - пріоритетний напрям в освіті XXI століття: проблеми, досягнення i перспективи» (м. Харків, 25-27 жовтня 2013 року) ${ }^{3}$, Шосту міжнародну науково-методичну конференцію «Практична медіаграмотність: міжнародний досвід та українські перспективи» (м. Київ, 20-21 квітня 2018 року) ; Сьому міжнародну

Матеріали Міжнародної науково-практичної інтернет-конференції «Медіаосвіта - пріоритетний напрям в освіті XXI століття: проблеми, досягнення і перспективи» (25-27 жовтня 2013 року) / за заг. ред. канд. пед. наук Л.Д. Покроєвої. Харків : Харківська академія неперервної освіти, 2013. С. 39.

2 Медіаграмотність на уроках суспільних дисциплін: Посібник для вчителя / за ред. В. Іванова, О. Волошенюк, О. Мокрогуза. Київ: Центр вільної преси, Академія української преси, 2016. С. 6. URL: https://www.slideshare.net/mobile/ssuser9b9413/ss63773058.

Матеріали Міжнародної науково-практичної Інтернет-конференції «Медіаосвіта - пріоритетний напрям в освіті XXI століття: проблеми, досягнення і перспективи» (25-27 жовтня 2013 року) / за заг. ред. канд. пед. наук Л.Д. Покроєвої. Харків : Харківська академія неперервної освіти, 2013.

4 Збірник статей Шостої міжнародної науково-методичної конференції «Практична медіаграмотність: міжнародний досвід та українські перспективи» / за ред. В. Іванова, О. Волошенюк. Київ : Центр вільної преси, Академія української преси, 2018. URL: https://www.aup.com.ua/uploads/Zbirnyk_statey_AUP2018.pdf. 
науково-методичну конференцію «Сучасний простір медіаграмотності та перспективи його розвитку» (м. Київ, 2019 року) ${ }^{5}$ тощо.

Рефлексією на поставлені завдання можна вважати посібник для вчителя «Медіаграмотність на уроках суспільних дисциплін»; курси $з$ медіаграмотності: двомовний онлайн-курс «Very Verified: онлайнкурс із медіаграмотності» (verified.ed-era.com), що стартував у вересні 2019 року; курси на платформі «Prometheus» - «Медіаграмотність для освітян», «Медіаграмотність: практичні навички», «Інтернет-медіа», «Інформаційні війни» (prometheus.org.ua) та інші.

Мета цієї розвідки - визначити зміст й окреслити шляхи інтегрування медіаграмотності в освітньо-професійну програму підготовки здобувачів вищої освіти.

\section{1. Шляхи інтегрування медіаграмотності в освітній простір здобувачів вищої освіти}

Значним кроком у формуванні безпечного інформаційного суспільства стало розроблення й затвердження «Концепції впровадження медіаосвіти в Україні», яка грунтується на вивченні рівня медіакультури населення України та міжнародному досвіді організації медіаосвіти. Основні положення Концепції відповідають завданням, сформульованим у Паризькій програмі-рекомендаціях із медіаосвіти ЮНЕСКО (від 22.06.2007 року) і резолюції Європарламенту щодо медіаграмотності у світі цифрової інформації (від 16.12.2008 року).

Ще одним кроком державного рівня є лист Міністерства освіти і науки України від 29.03.2013 року № 1/9-226 «Про запровадження вивчення курсу «Основи медіаграмотності» в навчальних закладах», у якому рекомендовано запровадити вивчення курсу «Основи медіаграмотності» у вищих педагогічних навчальних закладах за рахунок годин вибіркової частини освітньо-професійної програми ${ }^{7}$. На думку авторки цієї розвідки, медіаграмотність - необхідна навичка в контексті інформаційної агресії не тільки для майбутніх педагогів, a i всіх молодих людей, зокрема майбутніх офіцерів Національної гвардії України. Науково-педагогічний склад Національної академії

5 Збірник статей Сьомої міжнародної науково-методичної конференції «Сучасний простір медіаграмотності та перспективи його розвитку» / за ред. В. Іванова, О. Волошенюк. Київ : Центр Вільної Преси, Академія української преси, 2019.

${ }^{6}$ Медіаграмотність на уроках суспільних дисциплін: Посібник для вчителя / за ред. В. Іванова, О. Волошенюк, О. Мокрогуза. Київ: Центр вільної преси, Академія української преси, 2016. URL: https://www.slideshare.net/mobile/ssuser9b9413/ss-63773058.

Матеріали Міжнародної науково-практичної інтернет-конференції «Медіаосвіта - пріоритетний напрям в освіті XXI століття: проблеми, досягнення і перспективи» (25-27 жовтня 2013 року) / за заг. ред. канд. пед. наук Л.Д. Покроєвої. Харків : Харківська академія неперервної освіти, 2013. С. 40. 
Національної гвардії України активно корегує робочі програми навчальних дисциплін, уносячи компоненти, спрямовані на формування навичок критичного мислення й вироблення імунітету до медіаманіпуляцій і пропаганди.

Українське суспільство потребує вироблення навичок формування медійної й інформаційної грамотності в умовах пропагандистськопсихологічних війн ${ }^{8}$. Освітні заклади - саме ті інституції, які мають усі можливості для того, щоб долучитися до формування медіаграмотного споживача. Г. Онкович визначає магістральні шляхи інтегрування медіаграмотності в освітній простір: «Формування медіаграмотності майбутніх фахівців у межах вищих навчальних закладів може здійснюватися двома способами: через уведення окремого курсу з медіаосвіти або через інтеграцію медіаосвітніх технологій до вже наявної системи навчально-виховного процесу, зокрема завдяки виконанню міждисциплінарних досліджень 3 інформаційних, комунікаційних та освітніх наук, соціології та інших» ${ }^{9}$.

Дисципліна «Основи медіаграмотності» не нормативна, а тому викладається не в усіх вишах, але це не становить перешкоди для інтеграції елементів медіаосвіти в інші дисципліни. Так, у Національній академії Національної гвардії України аспекти медіаграмотності досліджуються на заняттях 3 «Основ теорії мовної комунікації», «Комунікативного аспекту діяльності військового командира», «Основ наукових досліджень», «Основ стратегічних комунікацій», «Комунікативної взаємодії Національної гвардії України з громадськістю» тощо.

Отже, окреслюється кілька способів уведення медіаграмотності в освітньо-професійну програму підготовки здобувачів вищої освіти: 1) упровадження окремого курсу; 2) запуск онлайн-курсу або мотивація здобувачів вищої освіти проходити наявні; 3 ) інтеграція окремих тем / змістових модулів / блоків змістових модулів до наявних у програмі дисциплін; 4) введення окремих вправ, що сприятимуть розвитку критичного аналізу медіаконтенту, у план занять з історії, іноземної мови, соціології, психології тощо.

8 Медіаграмотність на уроках суспільних дисциплін: Посібник для вчителя / за ред. В. Іванова, О. Волошенюк, О. Мокрогуза. Київ : Центр вільної преси, Академія української преси, 2016. С. 6-7. URL: https://www.slideshare.net/mobile/ssuser9b9413/ss-63773058

9 цит. за: Матеріали Міжнародної науково-практичної інтернет-конференції «Медіаосвіта - пріоритетний напрям в освіті XXI століття: проблеми, досягнення і перспективи» (25-27 жовтня 2013 року) / за заг. ред. канд. пед. наук Л.Д. Покроєвої. Харків: Харківська академія неперервної освіти, 2013. С. 40. 


\section{2. Зміст курсу з медіаграмотності для здобувачів вищої освіти}

Сучасна молода людина повинна набути компетентностей iз медіаграмотності, які «можна умовно поділити на чотири групи: розуміння медіа, використання медіа, комунікація за допомогою медіазасобів та вміння досягати власних цілей, застосовуючи медіа» ${ }^{10}$ (див. табл. 1).

Таблиця 1

10 компетентностей із медіаграмотності

\begin{tabular}{|c|c|c|c|c|c|c|c|c|c|}
\hline \multicolumn{3}{|c|}{ Розуміння } & \multicolumn{2}{|c|}{ Використання } & \multicolumn{3}{|c|}{ Комунікація } & \multicolumn{2}{|c|}{ Стратегія } \\
\hline 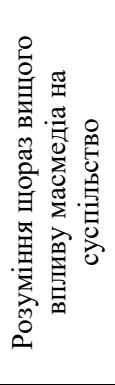 & 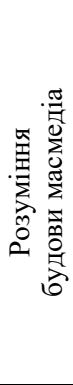 & 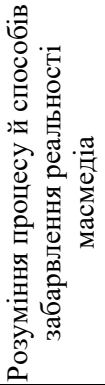 & 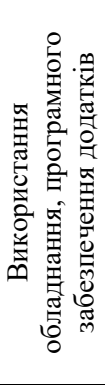 & 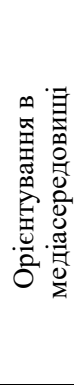 & 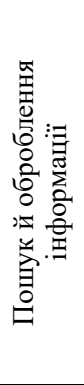 & 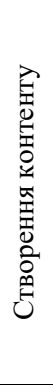 & 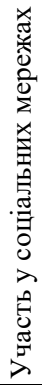 & 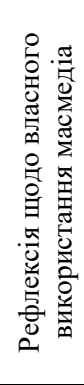 & 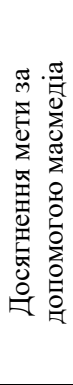 \\
\hline \multicolumn{3}{|c|}{$\begin{array}{c}\text { Пасивне розуміння } \\
\text { роботи медіа }\end{array}$} & \multicolumn{2}{|c|}{$\begin{array}{c}\text { Активне } \\
\text { використання } \\
\text { медіа }\end{array}$} & \multicolumn{3}{|c|}{$\begin{array}{c}\text { Взасмодія } \\
3 \text { іншими через } \\
\text { медіа }\end{array}$} & \multicolumn{2}{|c|}{$\begin{array}{c}\text { Ефективне } \\
\text { використання } \\
\text { медіа }\end{array}$} \\
\hline
\end{tabular}

Джерело: https://ms.detector.media/mediaosvita/post/18961/2017-05-24buti-mediagramotnim-desyat-neobkhidnikh-kompetentnostei/

Для послідовного формування компетентностей маємо визначити етапи реалізації медіаосвітніх підходів: 1) одержання знань про теорію мови медіа; 2) розвиток сприйняття медіатекстів; 3) розвиток креативних практичних умінь на матеріалі медіа ${ }^{11}$. Визначені компетентності й етапи реалізації медіаосвітніх підходів дають змогу впорядкувати логічну, послідовну програму «Основи медіаграмотності» як інтегрованого курсу для здобувачів вищої освіти, яка й визначає зміст медіаосвіти (див. табл. 2).

10 Бути медіаграмотним: десять необхідних компетентностей. URL: https://ms.detector.media/mediaosvita/post/18961/2017-05-24-buti-mediagramotnimdesyat-neobkhidnikh-kompetentnostei/

11 Матеріали Міжнародної науково-практичної Інтернет-конференції «Медіаосвіта - пріоритетний напрям в освіті XXI століття: проблеми, досягнення і перспективи» (25-27 жовтня 2013 року) / за заг. ред. канд. пед. наук Л.Д. Покроєвої. Харків: Харківська академія неперервної освіти, 2013. С. 16. 


\section{Таблиця 2}

Проєкт програми «Основи медіаграмотності»

\begin{tabular}{|c|c|c|}
\hline № & Tема & Навчальні питання \\
\hline 1 & $\begin{array}{l}\text { Роль масмедіа в житті } \\
\text { сучасної людини }\end{array}$ & $\begin{array}{ll}\text { 1. } & \text { Масмедіа як джерело інформації. } \\
\text { 2. } & \text { Медіазвички здобувачів вищої освіти. } \\
\text { 3. } & \text { Типи контенту. } \\
\text { 4. } & \text { Факт і судження. } \\
\text { 5. } & \text { Новинна грамотність. } \\
\text { 6. } & \text { Свідоме медіаспоживання. } \\
\end{array}$ \\
\hline 2 & Традиційні медіа & $\begin{array}{ll}\text { 1. } & \text { Типи традиційних медіа. } \\
\text { 2. } & \text { Власники медіа. }\end{array}$ \\
\hline 3 & Редакційна політика & $\begin{array}{ll}\text { 1. } & \text { Редакційна політика. } \\
2 . & \text { Громадянська журналістика. } \\
\text { 3. } & \text { Військова журналістика. } \\
\text { 4. } & \text { Журналістські стандарти. } \\
\text { 5. } & \text { Свобода слова та цензура. }\end{array}$ \\
\hline 4 & Соціальні медіа & $\begin{array}{l}\text { 1. Соціальні медіа як джерело новин. } \\
\text { 2. «Інформаційна бульбашка» } \\
\text { та як із неї вирватися. } \\
\text { 3. Боти, тролі й групи в соціальних } \\
\text { мережах. } \\
\text { 4. Стереотипи й мова ворожнечі. } \\
\text { 5. Синдром злого світу. }\end{array}$ \\
\hline 5 & $\begin{array}{l}\text { Дезінформація та } \\
\text { медіаманіпуляція }\end{array}$ & $\begin{array}{ll}\text { 1. } & \text { Типи маніпулятивного контенту. } \\
\text { 2. } & \text { Маніпулятивні медіатехнології. } \\
\text { 3. } & \text { Наратив як спосіб маніпулювання. } \\
\text { 4. } & \text { Маніпулятивні заголовки. } \\
\text { 5. } & \text { Дезінформація та політична змова. } \\
\text { 6. } & \text { Фотофейки. } \\
7 . & \text { Фейкові експертні коментарі. } \\
\text { 8. } & \text { Маніпуляції з першоджерелами. } \\
9 . & \text { Сервіси для фактчекінгу. } \\
\text { 10. } & \text { Матеріал на замовлення, або джинса. } \\
\text { 11. } & \text { Маніпуляції в рекламі. }\end{array}$ \\
\hline 6 & Підсумок & Фінальний проєкт \\
\hline
\end{tabular}

Люди, які володіють навичками медіаграмотності, можуть:

- «розуміти вплив медіа та форми подання інформації в них;

- ухвалювати поінформовані та незалежні рішення;

- отримувати нову інформацію про навколишній світ;

- формувати почуття спільності;

- підтримувати публічний дискурс;

- продовжувати навчання протягом життя;

- створювати інформацію;

- мислити критично; 
- використовувати медіа для самовираження і творчості;

- використовувати медіа, дотримуючись засад безпеки та відповідальності;

- брати участь у житті демократичного суспільства та глобальної інформаційної мережі» ${ }^{12}$.

Мета курсу з медіаграмотності - озброїти здобувачів вищої освіти інструментами критичного аналізу медіаконтенту, розвивати інтерактивні навички (здатність спілкуватися за допомогою медіа й виконувати різні медіаролі) та креативність, яка полягає у формуванні навичок створювати й інтерпретувати медіаконтент.

\section{3. Приклади вправ і завдань для розвитку медіаграмотності}

Формати проведення занять: комунікативні ігри, експерименти, вебквести, воркшопи, тести, робота з першоджерелами (аналіз постерів, медіастатей, інтерв'ю, дописів у соціальних мережах тощо). Здобувачі вищої освіти працюють у парах чи командах, індивідуально.

\section{1. Вправи на розрізнення фактів і суджень}

Вправа 1. Доберіть і продемонструйте фото, на якому зображено явище природи, й метафорично опишіть відчуття, які у Вас викликає це фото. Запитайте в інших членів групи про їхні відчуття, що виникають під час перегляду цієї ж фотографії. Розмежуйте факт і судження у вашій комунікативній активності. Поясніть, як виникають інтерпретації, тобто судження, стосовно вербального декодування одного й того самого факту.

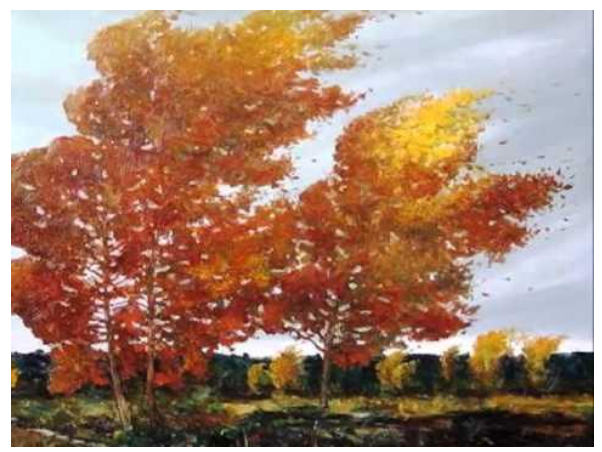

Рис. 1. Приклад фото

Джерело фото: https://cutt.ly/XgOlHg9

${ }^{12}$ Медіаграмотність на уроках суспільних дисциплін: Посібник для вчителя / за ред. В. Іванова, О. Волошенюк, О. Мокрогуза. Київ : Центр вільної преси, Академія української преси, 2016. С. 15. URL: https://www.slideshare.net/mobile/ssuser9b9413/ ss-63773058. 
Вправа 2. Ознайомтесь із медіастаттею (за посиланням (тут $i$ далi посилання бажано давати на свіжі новини) https://www.pravda.com.ua/news/2020/10/31/7271938/) і заповніть таблицю.

\begin{tabular}{|c|c|}
\hline Факти & Судження \\
\hline & \\
\hline
\end{tabular}

Прочитайте коментарі, які залишили медіаспоживачі. Дайте відповідь на питання:

- Яких аспектів статті стосуються коментарі?

- До фактів чи до суджень апелюють коментатори?

- Які коментарі вважаєте коректними, чому?

- Які коментарі варто видалити, чому?

Сформулюйте власний коментар до цієї статті.

Вправа 3. Ознайомтесь із медіастаттями однієї й тієї ж рубрики одного й того ж видання:

- https://lifestyle.24tv.ua/dmitro-komarov-rozchuliv-dityachimi-fotonovini-shou-biznesu_n1461528;

- https://lifestyle.24tv.ua/irina-fedishin-prodala-kvartiru-bolgariyinovini-shou-biznesu_n1461615;

- https://lifestyle.24tv.ua/andzhelina-dzholi-ne-vidstoronila-suddyunovini-shou-biznesu_n1461395;

- https://lifestyle.24tv.ua/pomer-znamenitiy-rezhiser-romanviktyuk_n1461812;

- https://lifestyle.24tv.ua/katerina-kuhar-prokomentuvala-vilit-melnikanovini-shou-biznesu_n1461333;

- https://lifestyle.24tv.ua/masha-yefrosinina-pokazala-yakzminyuvalas-novini-shou-biznesu_n1461286.

Кожен із Вас має обрати одну статтю, яка не збігатиметься 3 вибором одногрупника. Заповніть таблицю, скориставшись пам'яткою, розміщеною наприкінці вправи.

\begin{tabular}{|c|c|c|}
\hline Факти & Судження/інтерпретація & Слова-маркери \\
\hline & & \\
\hline
\end{tabular}

Дайте відповіді на запитання:

- Яка 3 колонок таблиці виявилася заповненою більше - фактів чи суджень? Порівняйте свою таблицю 3 таблицями одногрупників. Чи помітили Ви суттєві відмінності в кількості виявлених фактів і суджень у їхніх таблицях порівняно зі своєю? Спробуйте обгрунтувати свої спостереження.

- Що Ви визначили як факти?

- Що Ви диференціювали як судження?

- Яка мета цього контенту? Хто його цільова аудиторія?

- Як Ви зазвичай реагуєте на контент такої тематичної категорії? 
- Які корективи Ви внесли б у цей текст (або рубрику)?

- Чиї ідеї та переконання відображені в тексті, а чиї проігноровані?

- Чи немає в автора упередженого ставлення до героя публікації?

- Чи помітили Ви спільні слова-маркери, порівнюючи свою таблицю 3 таблицями одногрупників? Спробуйте згрупувати словамаркери. Визначте продуктивні групи й ті, які представлені поодинокими випадками. Поясніть, вибір такої стратегії авторами.

\section{Пам'ятка}

Щоб розпізнати думку і відрізнити ії від факту, не забувайте, що:

- думка суб'єктивна, а факт об'єктивний. Факт існує незалежно від нашого бажання або ставлення до нього;

- факт - завжди істина. Думка, щоб бути істиною, має спиратися на факти і ії істинність повинна бути обгрунтована;

- думка завжди має авторство (сумлінний автор, висловлюючи свою думку, підписується, а передаючи чужу думку, він указує, кому вона належить);

- якщо думку виражають відкрито, то це супроводжується словами: думаю, щуо ...; вважаю, що ...; по-моєму ...; мені здається, що ... або іншими близькими за змістом словосполученнями;

- думка може «ховатися» за фразами на кшталт: це означає ...; щзо свідчить ...; або взагалі ніяк «не проявляти себе», зливаючись із фактом. Наприклад: «Я не знаю, яка погода. Одягнися тепло!».

Джерело пам'ятки: https://aup.com.ua/books/mbm/\#r2

Вправа 4. Прочитайте статтю (https://glavcom.ua/news/viboriprezidenta-ssha-yak-amerikanci-obirayut-prezidenta-golovne-715583.html) i виділіть різнокольоровими маркерами судження (жовтим), факти без посилання на джерело (оранжевим), факти з посиланням на джерело (зеленим). Дайте відповіді на запитання:

- Якою стратегією варто користуватися, щоб відрізнити факти від суджень?

- У чому відмінність факту й судження?

- Матеріали, які Ви зазвичай читаєте, базуються на фактах чи судженнях? Обгрунтуйте свою відповідь, підтвердивши ії прикладами. 
3.2. Вправи до теми «Власники медіа»

Вправа 1. Заповніть таблицю «Кому належать вітчизняні телеканали?».

Кому належать вітчизняні телеканали?

\begin{tabular}{|c|c|c|}
\hline $\begin{array}{c}\text { Номер } \\
\mathbf{3 / \mathbf { I }}\end{array}$ & Телеканал & Власник(и) \\
\hline 1 & $1+1$ & \\
\hline 2 & 5 канал & \\
\hline 3 & Інтер & \\
\hline 4 & ICTV & \\
\hline 5 & СТБ & \\
\hline 6 & $2+2$ & \\
\hline 7 & Новий канал & \\
\hline 8 & UВR & \\
\hline 9 & Мега & \\
\hline 10 & ТРК Україна & \\
\hline
\end{tabular}

Вправа 2. Заповніть таблицю «Кому належать вітчизняні радіостанції?», скориставшись довідкою.

Кому належать вітчизняні радіостанції?

\begin{tabular}{|c|c|c|}
\hline $\begin{array}{c}\text { Номер } \\
\text { 3/п }\end{array}$ & Радіостанція & Власник(и) \\
\hline 1 & Люкс FM & \\
\hline 2 & Перець FM & \\
\hline 3 & Радіо «Вести» & \\
\hline 4 & Радіо Ера & \\
\hline 5 & Свропейська станція & \\
\hline 6 & Радіо група UМН & \\
\hline 7 & Бізнес радіо груп & \\
\hline 8 & Радіо група «Тавр Медіа» & \\
\hline
\end{tabular}

Довідка: М. Баграєв, А. Деркач, А. та Є. Євтухови, А. Карпій, О. Клименко, С. Курченко, родина А. Садового, RadioCorp Holding.

Вправа 3. Установіть відповідність «Кому належать вітчизняні медіа?».

Кому належать вітчизняні медіа?

\begin{tabular}{|c|c|}
\hline Главред (http://glavred.info/) & 1. Влада \\
\hline IHTEP + & 2. С. Курченко \\
\hline Перший Національний & 3. Д. Фірташ, С. Льовочкін \\
\hline 4. Коментарі (comments.ua) & 4. М. Баграєв \\
\hline 5. HTH & 5. С. Арбузов, О. Янукович \\
\hline 6. Forbes Україна (http://forbes.ua/) & 6. І. Коломойський \\
\hline Українська правда & 7. А. та Є. Свтухови \\
\hline 8. Капітал (http://www.capital.ua/) & 8. А. Карпій \\
\hline 9. Бізнес радіо груп & 9. О. Притула \\
\hline 10. Радіогрупа «Тавр Медіа» & 10. Р. Ахметов \\
\hline
\end{tabular}


Вправа 4. Доберіть статті з видань, що перебувають у власності I. Коломойського, С. Курченка, Ю. Бутусова, В. Пінчука, за однією й тією ж самою темою. Розмежуйте факти й судження в дібраних публікаціях. Виявіть спільне й відмінне в судженнях, що представлені в дібраному матеріалі. Поміркуйте, чим зумовлені відмінності в інтерпретації фактів і формулюванні суджень у цих публікаціях.

Вправа 5. Доберіть фото, що доповнюють матеріал, опублікований у виданнях, які належать Р. Ахметову, С. Арбузову й О. Януковичу, Ю. Мостовій, «Інтермедіа консалтингу» (В. Медведчуку, Д. Сагачу, Г. Герман). Порівняйте контекст, у який «вкручено» відповідні фото. Перевірте, чи не зазнали фото маніпулятивних змін. Поміркуйте, чи відповідають фото заявленим заголовкам, чи не суперечать вони викладеному матеріалу. Якщо так, то спробуйте пояснити, чим це зумовлено.

\section{3. Вправи на виявлення медіаманіпуляцій}

Вправа 1. Перегляньте стрічку Google-новин у своєму смартфоні. За заголовками виберіть контент, який Вас зацікавив. Поясніть, чим він Вас зацікавив. Укажіть на контент, із яким Ви ознайомитеся, який поширите, а який прокоментуєте. До якого матеріалу Ви залишили б позитивний/негативний коментар? Поясніть свої дії. Розмежуйте якісний і маніпулятивний контент. Заголовки до якого матеріалу не виправдали Ваших сподівань?

Вправа 2. Ознайомтеся із медіазаголовками в інтернет-виданнях:

- Зеленський про рішення КС: Чорти відкривають справжні обличчя (https://www.pravda.com.ua/news/2020/11/1/7271992/);

- Зеленський написав статтю в FT про ситуацію з КС (https://ua.korrespondent.net/ukraine/4290604-zelenskyi-napysav-stattui-vFT-pro-sytuatsiui-z-ks);

- Україна зазнала нападу не лише на своїх кордонах - Зеленський про рішення КСУ (https://www.unian.ua/politics/shcho-govorit-zelenskiypro-ksu-ukrajina-zaznala-napadu-ne-lishe-na-svojih-kordonah-noviniukrajina-11202800.html);

- «Права рука» голови КСУ навчався в одному виші з отруювачем Скрипалів (https://plus.obozrevatel.com/ukr/crime/prava-ruka-golovi-ksunavchavsya-v-odnomu-vishi-z-otruyuvachemskripaliv.htm?_ga=2.160338489.561868383.1604257693426023401.1586371038).

Спробуйте передбачити інформаційне наповнення матеріалу, давши відповідь на питання:

- Чи зацікавили Вас запропоновані заголовки?

- Чи достатньо інформативні запропоновані заголовки? 
- Що нового Ви хотіли би дізнатися 3 матеріалу, який має відповідні назви?

Сформулюйте питання, відповіді на які Ви би хотіли отримати після ознайомлення із матеріалом.

Ознайомтеся із текстом публікацій, заголовки яких опрацювали, за відповідними посиланнями. Дайте відповіді на питання:

- Чи відповідає заголовок тексту публікації?

- Чи виправдали заголовки Ваші інформаційні запити?

- Чи отримали Ви відповіді на питання, що виникли після прочитання заголовка?

Виявіть маніпулятивні заголовки. Визначте маніпулятивні технології, застосовані до них. Запропонуйте свої варіанти заголовків до відповідного матеріалу.

\section{4. Завдання до теми «Соціальні мережі»}

Підготуйте допис, орієнтований на поширення в соціальних мережах, на одну із запропонованих тем. Репрезентуйте його одногрупникам. Проведіть дискусію з розподілом медіаролей: блогер (автор допису) і фоловер, френд, проплачений коментатор, хейтер, хайпер. Під час обговорення підтримуйте інтенцію, передбачену Вашою медіароллю.

\section{Теми для обговорення}

(аспект розкриття теми виберіть самостійно або орієнтуйтеся на поради викладача)

- здорове харчування;

- гендерний паритет в армії;

- гендерна рівність у сім'і;

- спорт у житті кожного;

- ЛГБТ-спільноти;

- лідерство й управління;

- лідерство як мистецтво впливу на людей;

- медіаграмотність підлітків та їх батьків;

- конфлікт та способи його вирішення;

- міжкультурний конфлікт на сторінках художньої літератури;

- етикет у різних країнах (культурах);

- невербальні елементи міжкультурної комунікації;

- стратегії і тактики проведення дипломатичних переговорів;

- соціальні мережі як джерело інформації;

- мода як спосіб самовираження;

- мова ворожнечі в соціальних мережах.

Запропоновані вправи варто сприймати як «правила гри», добираючи контент з англомовних, франкомовних та інших сайтів за темою заняття, в яке буде інтегровано ту чи іншу вправу. 
Наприкінці вивчення матеріалу здобувачі вищої освіти готують і репрезентують індивідуальні фінальні проєкти (див. табл. 3): пишуть дописи, знімають відео чи фото, створюють медіапрезентації, меседжі та медіамеседжі, приміряючи на себе різні медіаролі (зірки медіа, блогера, влогера, інтерв'юера чи інтерв'юйованого, репортера, підписника, проплаченого коментатора, хейтера, хайпера). Пропонований проєкт можна використати і як окреме самостійне завдання.

Метод проєктів обрано не зовсім випадково, адже саме проєктна технологія сприяе «розвитку пізнавальних навичок, критичного мислення, вміння самостійно конструювати свої знання, орієнтуватися в інформаційному просторі, вміння побачити, сформулювати і вирішити проблему» ${ }^{3}$. Тип проєкту (інформаційний, творчий, практико орієнтований, дослідницький ${ }^{14}$ ) здобувачі вищої освіти обирають самостійно, зазвичай це інформаційні й дослідницькі типи. Отже, така форма підсумкового контролю дає змогу створити комфортне конструктивно-критичне середовище, близьке до реальних умов молодіжного медіапростору.

Таблиця 3

Приклад фінального проскту

\begin{tabular}{|c|c|}
\hline $\begin{array}{c}\text { ОСНОВИ ТЕОРЇ̈ } \\
\text { МОВНӦ̈ КОМУНІКАЦЇ }\end{array}$ & ФІНАЛЬНИЙ ПРОСКТ \\
\hline $\begin{array}{l}\text { 1. Створити меседж за темою: } \\
\text { «Конфліктна поведінка в } \\
\text { молодіжному середовищі як } \\
\text { криміногенний фактор» }\end{array}$ & $\begin{array}{l}\text { 4. Створити допис у соціальних } \\
\text { мережах, присвячений конфлікту } \\
\text { та способам його вирішення }\end{array}$ \\
\hline $\begin{array}{l}\text { 2. Створити контент (відео) на тему } \\
\text { «Емоції у засобах масової } \\
\text { інформації. Як ТV-видання } \\
\text { змінюють реальність» }\end{array}$ & $\begin{array}{l}\text { 5. Медіапрезентація «Міжнародний } \\
\text { дисонанс чи консонанс?»: розробіть } \\
\text { правила запрошення перекладачів } \\
\text { для участі в ділових переговорах між } \\
\text { українцями і французами / німцями / } \\
\text { американцями }\end{array}$ \\
\hline $\begin{array}{l}\text { 3. Створити допис для своїх } \\
\text { підписників у соціальних мережах, } \\
\text { присвячений міжкультурній } \\
\text { комунікації }\end{array}$ & $\begin{array}{l}\text { 6. Підготувати медіамеседж для } \\
\text { підлітків та їх батьків, присвячений } \\
\text { медіаграмотності }\end{array}$ \\
\hline
\end{tabular}

${ }^{13}$ Ільчук В.В. Використання освітніх електронних ресурсів у процесі викладання української мови. Modern researches in philological sciences: Collective monograph. Riga: Izdevnieciba "Baltija Publishing", 2020. C. 93.

${ }^{14}$ Там само. С. 94. 


\section{ВИСНОВКИ}

Уміння протистояти негативним інформаційним впливам, маніпуляціям, дезінформації; уважно добирати, аналізувати й обробляти медіаконтент; створювати власний якісний контент з урахуванням інтересів своєї цільової аудиторії; досягати власної мети за допомого масмедіа - усе це $є$ невід'ємним складником розвитку сучасної особистості, тому необхідно впроваджувати елементи медіаграмотності в навчальний процес здобувачів вищої освіти у вигляді окремої дисципліни чи у формі інтеграції до чинного навчального плану відповідного напряму підготовки (спеціальності).

Інтегровані теми чи зміст самостійного курсу мають орієнтуватися на компетентності й програмні результати, якими повинен володіти здобувач вищої освіти відповідного напряму підготовки. Завданням курсу $є$ не тільки надати необхідні знання, вміння й навички для успішного медіакористування, а й мотивувати до подальшого свідомого i/чи креативного інтерпретування й продукування медіапродукції.

Заняття 3 медіаграмотності варто проводити в доброзичливій атмосфері в дусі здорової конкуренції та конструктивної критики. Студенти нечасто піддають сумніву інстаграмну комунікативну модель, уважають іiі придатною для публічного спілкування й безапеляційно копіюють iï. Викладач має пробуджувати креативний потенціал, стимулювати самостійну роботу здобувачів вищої освіти, «втягувати» молодих людей в офлайн-спілкування.

Елементи медіаграмотності «конектяться» 3 матеріалом суспільногуманітарного циклу дисциплін, активізують роботу 3 першоджерелами, викликають зацікавлення в здобувачів вищої освіти (оскільки вчаться вони у звичному середовищі), дають змогу розвивати толерантність до інших думок, суджень, тверджень.

Форми і способи вираження медіа постійно розвиваються, а отже, навички медіаграмотності також повинні постійно вдосконалюватися. Цим і зумовлена перспектива подальших розвідок у цьому напрямі.

\section{АНОТАЦІЯ}

У цій розвідці актуалізовано питання впровадження основ медіаграмотності в освітньо-професійну програму підготовки здобувачів вищої освіти, що в сучасному інформаційному суспільстві України постало особливо гостро. Окреслено шляхи інтегрування медіаграмотності в освітній простір здобувачів вищої освіти. Визначено мету курсу медіаграмотності, а саме: озброїти здобувачів вищої освіти інструментами критичного аналізу медіаконтенту, розвивати інтерактивні навички та креативність, яка полягає у формуванні навичок створювати й інтерпретувати медіаконтент. Запропоновано проєкт програми «Основи медіаграмотності» як перелік 
основних питань для аналізу сучасного медіапростору. Наведено приклади вправ і завдань, що орієнтовані на інтегрування в наявні дисципліни програми підготовки здобувачів вищої освіти. Вправи й завдання відповідають темам, які передбачені програмою і темарієм вивчення медіаграмотності. Представлено зразок фінального проєкту, який здобувачі вищої освіти мають готувати наприкінці вивчення тем із медіаграмотності, пробуджуючи власний креативний потенціал.

\section{ЛІТЕРАТУРА}

1. Бути медіаграмотним: десять необхідних компетентностей. URL: https://ms.detector.media/mediaosvita/post/18961/2017-05-24-butimediagramotnim-desyat-neobkhidnikh-kompetentnostei/

2. Збірник статей Сьомої міжнародної науково-методичної конференції «Сучасний простір медіаграмотності та перспективи його розвитку» / за ред. В. Іванова, О. Волошенюк. Київ : Центр Вільної Преси, Академія української преси, 2019. 435 с.

3. Збірник статей Шостої міжнародної науково-методичної конференції «Практична медіаграмотність: міжнародний досвід та українські перспективи» / за ред. В. Іванова, О. Волошенюк. Київ : Центр вільної преси, Академія української преси, 2018. 244 с. URL: https://www.aup.com.ua/uploads/Zbirnyk_statey_AUP2018.pdf

4. Ільченко О. Медіаграмотність в освітньо-професійній програмі підготовки здобувачів вищої освіти. Актуальні питання гуманітарних наук: міжвузівський збірник наукових праџь молодих вчених Дрогобичького державного педагогічного університету імені Івана Франка / ред.-упорядн. М. Пантюк, А. Душний, І. Зимомря. Дрогобич : Видавничий дім «Гельветика», 2020. Вип. 28. Том 2. С. 113-119. DOI: https://doi.org/10.24919/2308-4863.2/28.208652.

5. Ільченко О.А. Медіазвички здобувачів вищої освіти та «інформаційна бульбашка» як заклик до впровадження уроків медіаграмотності. International scientific and practical conference "Current trends and factors of the development of pedagogical and psychological sciences in Ukraine and EU countries": conference proceedings, September 25-26, 2020. Lublin: Izdevnieciba "Baltija Publishing", 2020. P. 207-210. DOI: https://doi.org/10.30525/978-9934588-80-8-2.55.

6. Ільчук В.В. Використання освітніх електронних ресурсів у процесі викладання української мови. Modern researches in philological sciences: Collective monograph. Riga: Izdevnieciba "Baltija Publishing", 2020. C. 85-101. DOI: https://doi.org/10.30525/978-9934-588-37-2/6.

7. Матеріали Міжнародної науково-практичної Інтернетконференції «Медіаосвіта - пріоритетний напрям в освіті XXI століття: проблеми, досягнення і перспективи» (25-27 жовтня 2013 року) / за заг. 
ред. канд. пед. наук Л.Д. Покроєвої. Харків : Харківська академія неперервної освіти, 2013. 268 с.

8. Медіаграмотність на уроках суспільних дисциплін: Посібник для вчителя / за ред. В. Іванова, О. Волошенюк, О. Мокрогуза. Київ : Центр вільної преси, Академія української преси, 2016. 201 с. URL: https://www.slideshare.net/mobile/ssuser9b9413/ss-63773058.

\section{Information about the author:} Ilchenko O. A., Candidate of Philological Sciences, Associate Professor at the Department of Philology, Translation and Strategic Communication National Academy of the National Guard of Ukraine 3, Zakhysnykiv Ukrayiny square, Kharkiv, 61001, Ukraine 